\title{
PANDEMIA: SEUS DESAFIOS E ENSINAMENTOS
}

\author{
Júlia Steiner Pugem \\ Natália Duarte Machado Pinto \\ DOI: http://dx.doi.org/10.18616/intcov20
}

Se as pessoas soubessem que em questão de poucos dias estariam isoladas, dentro de suas casas, sem poder sair para nada além de tarefas realmente necessárias, será que seriam diferentes antes desta pandemia iniciar? Será que pensariam e agiriam mais em relação a tudo que as rodeia? Será que dariam mais valor à vida e se importariam menos com coisas que não acrescentam em nada?

E se pudessem prever tudo isso? Para algumas pessoas a rotina mudou, e para a maioria delas foi uma mudança drástica. Esse turbilhão pegou de "surpresa" o mundo inteiro. Quem sabe, se conseguissem prever o que realmente estava por vir, teriam se esforçado para conhecer lugares diferentes que desejavam, dariam mais valor à própria liberdade, valorizariam as pessoas que convivem, os amigos, a família, os colegas de trabalho. Organizariam, talvez, as questões financeiras caso previssem que seria necessário, e o dia a dia poderia ser ainda melhor se ao invés de caírem na rotina fizessem algo por si e pelo outro, em forma de agradecimento.

Durante todo o caos, depois de ler, assistir e ouvir notícias ruins diariamente, sem poder mudar a realidade, as pessoas tentam constantemente se adaptar nesse novo ritmo, nessa nova forma de viver que foi imposta tão repentinamente. $\mathrm{O}$ sofrimento, a ansiedade, a angústia de não saber sobre o amanhã, torturam a mente da maior parte da população. Esse novo cenário exige olhar para o outro, mesmo sendo pela tela de um computador ou por uma ligação, com mais empatia. As pessoas precisam umas das outras. É necessário que todos estejam conectados para seguirem em frente. $\mathrm{O}$ universo inteiro está tentando compreender qual o seu papel na sociedade e se adaptar à nova realidade. 
Diante de tudo isso, é preciso lembrar das lições boas que surgiram. Muitos estão aprendendo ou reaprendendo a conviver com as pessoas de sua casa e com a sua própria companhia. As pessoas começaram a observar o que antes passava despercebido na correria do dia a dia, como um simples canto de um pássaro, o céu azul e o pôr do sol, mesmo sabendo que isso sempre esteve ali. A vida se reinventou. Amigos e familiares se conectam para amenizar um pouco da saudade que sentem, o abraço é falado diariamente como algo que todos esperam poder dar mais valor e entregá-lo a quem amam o mais rápido que puder.

E qual será a real lição que essa pandemia deixará? Será que as pessoas estão mesmo preparadas para realizar todas as maravilhas que desejam e falam? Será que todas estão dispostos a deixar tudo de ruim e que não faz bem para si e para o próximo para trás e serem diferentes? E se tudo voltar ao "normal" amanhã? Estarão determinadas a fazer um mundo novo?

Que a partir dessa leitura, todos aprendam que a pandemia quer ensinar muito, em especial o que diz nesta canção: "devia ter amado mais, ter chorado mais, ter visto o sol nascer, devia ter arriscado mais, e até errado mais, ter feito o que eu queria fazer. Queria ter aceitado, as pessoas como elas são. Devia ter complicado menos, trabalhado menos, ter visto o sol se pôr. Devia ter me importado menos, com problemas pequenos, ter morrido de amor. Queria ter aceitado a vida como ela é, a cada um cabe alegrias e a tristeza que vier..." e que jamais esqueçam da real importância que todos têm aqui, onde estão e quem realmente são. 